\title{
Kogeomefi: Innovation in Dance Creation Method Based on Social Media by Ferry Cahyo Nugroho
}

\author{
Rizki Oktaviani $^{1 *}$, Rumi Wiharsih ${ }^{2}$
}

\author{
${ }^{1}$ Graduate Program, Yogyakarta State University, Yogyakarta, Indonesia \\ ${ }^{2}$ Faculty of Languages and Arts, Yogyakarta State University, Indonesia \\ *Corresponding author. Email: rizkiocktavia@gmail.com
}

\begin{abstract}
Innovation is a process of renewing an existing culture or resource or producing a new product. The renewal process is usually driven by a feeling of dissatisfaction and curiosity that arises in individuals or groups of people, with the aim of improving the quality of life or to get social recognition for achievements. Kogeomefi is a virtual-based dance creation method through Instagram as the connecting platform. The term was first coined by a dance artist from Jember named Ferry Cahyo Nugroho. Kogeomefi comes from the words "choreography" and "geometry." Choreography is the process of designing movements into a unified dance piece, while geometry refers to lines and spatial shapes created by the human body. In this method, geometric shapes are depicted through motion poses. The way this method works is by collecting the motion poses from collaborators posted to their respective Instagram stories, which are then brough together into a complete unit of motions. The final result of this process is posted to the Instagram account, so that they can be accessed anytime and anywhere by the audience, which in this case are Instagram users. This collaborative work aims as an effort to stay connected with many people and remain productive amid the pandemic and the social restrictions that are being implemented in Indonesia. At the same time, it is hoped that it can become a medium of education and appreciation for dance for various levels of society.
\end{abstract}

\section{Keywords: Kogeomefi, Innovation in dance creation method, Based on social media}

\section{INTRODUCTION}

The increasingly rapid development of technology, particularly the internet, has helped all sectors of human activities and job to become more effective and efficient. The widespread network has brought human civilization into an all-digital age which allows us to obtain information more easily and quickly. The digital age began with the invention of computers and network-based technology, followed by the advanced smartphone technology, to the development of various supporting software and applications, including social media.

The world is currently in the midst of a prolonged health crises caused by the Covid-19 pandemic. This significantly affects various aspects of life, especially the economy and education, paralyzing the activities of society and significantly affecting the productivity. Various countries across the world have made efforts to restrict the spread of the virus by making new policies that must be followed by the citizens. Indonesia, while issuing a set of new policies to suppress the spread of the virus, is determined to advise the citizens to stay productive despite the limitations of the large-scale social restrictions and the notion of the "new normal".
This policy requires people to maintain physical and social distance, not make or join large gatherings, and apply new habits of clean and healthy lifestyle.

These circumstances ultimately force institutions and companies to "work from home", in which people must conduct all activities and work from home and online. Face-to-face physical meetings must be adapted to online and virtual meetings by phone, video conference applications, and other social media platforms. This then prompts a dance artist named Ferry Cahyo Nugroho to create a dance creation method which uses the social media of Instagram. He argues that the "work from home" policy has made people dormant and lack of activities, especially artists and art workers. Many of them have not been productive since the pandemic has limited their room for activities. This is where the virtual-based dance collaboration is created by using the social media Instagram, by the name of Kogeomefi.

This paper depicts the creation process of a virtualbased dance with Instagram as the facilitating media named Kogeomefi in the current age of advanced technology where impossible things become possible. As suggested by this paper, social media that is 
typically used for communication and entertainment, has now become the media for creation and education.

\section{LITERATURE REVIEW}

\subsection{Innovation}

Innovation can be regarded as a novelty, and refers to a process of turning a particular resource into more meaningful new products to improve the life quality of a community. Innovation and novelties cannot be separated from two interrelated special stages, namely discovery and invention. Discovery refers to a process of finding either a new tool or idea created by individuals or groups of society, while in the invention stage, the finding may never exist before, hence requiring recognition, acceptance, and application of said finding or novelty in the community [3].

The innovation process does not just occur out of the blue, as there is absolutely a drive within the individual or group of community, particularly in regard to the dissatisfaction of the current state of things and desire to improve the quality of life. This factor ultimately triggers the individual to attempt improving the flaws of a certain culture. The innovation process certainly never stops, even today in the highly advanced technological era where impossible things may become possible.

\subsection{Social Media}

According to Gohar [1], social media is a digital platform which allows its users to create and access information easily. Examples of social media include Youtube, Facebook, Whatsapp, Instagram, Line, Twitter, Google, Tiktok, etc. Below are some of the characteristics of social media:

a) Interactive;

b) A user-based platform where the shared information is controlled by the user;

c) The user is the content maker (texts, images, videos, audio); d) The user is free to determine the setting;

e) There is $a$

connection and interaction between users;

f) Unlimited connection.

As part of the current development of technology, social media certainly has various benefits for its users, including:

a) As the communication media which allows the users to be connected with one another in an unlimited way through the use of internet access;

b) As the media for education, with the abundant resources of easily accessible information and learning content;

c) As the media for entertainment and creation, the currently popular social media has the opportunity to make money for content creators.

On the other hand, many irresponsible people use the media as a means for disseminating fake news, hate speech, violent and immoral content that have a negative impact on the general public, especially the young generation.

\section{RESEARCH METHOD}

This study used the qualitative descriptive method. The data were collected by interviews and literature studies. Interviews were conducted directly with the creator of Kogeomefi by phone to obtain an in-depth understanding on the research topic. The literature study was done by studying the videos discussing the Kogeomefi method and observing the process and works uploaded by the artist on Instagram. The data analysis was conducted by focusing the attention on the research topic ang generating data in the form of a text depicting the observation in the study. 


\section{RESULTS AND DISCUSSION}

\subsection{The Creative Process of Ferry Cahyo Nugroho}

Creating art cannot be separated from the creative process of the artist. Ferry Cahyo Nugroho is a dance artist from Jember, East Java, and the initiator of the virtual dance project Kogeomefi, which comes from the words "choreography" and "geometry". Choreography is the process of arranging dance motions into a complete unified piece [2], while geometry is a branch of mathematics which studies lines, points, shapes, and space that are interrelated [5]. Geometry is imagined as the lines and shapes formed by the human body and motions. Kogeomefi is a virtual dance collaborative project which uses Instagram as the facilitating platform. The project began with Ferry experimenting by himself by making records or logs of his activities in a week. The notes were transformed into geometrical shapes and lines which form certain patterns.

Figure 1. Notations in geometry

The lines in Figure 1 represent the hand movements created by the body, while the two-dimensional shapes represent the foot forms, and the colors determine the transition of movements from one pose to another.

Tabel 1. Description of the transition in colors

\begin{tabular}{|l|l|l|}
\hline $\begin{array}{l}\mathbf{N} \\
\mathbf{o}\end{array}$ & Color & Movement transition \\
\hline 1. & Red & Spinning \\
\hline 2. & Blue & Closing the feet/ staying still \\
\hline 3. & Green & Bending the body \\
\hline 4. & Yellow & Jumping \\
\hline
\end{tabular}

Kogeomefi is a follow-up project from Ferry's previous work entitled Living Room which talks about space and boundaries. Space and boundaries are closely related to the current pandemic that hit the world, causing many activities to be hampered and even dormant for a while. Many people and workers feel the impact, including art workers. In the process of creating a dance piece, there is typically an interaction between the choreographer and dancers and other supporting elements, which is not possible to recreate during a pandemic, especially because of the social restrictions that are applied in Indonesia.

This is the background of why Ferry created a project that is based on the social media Instagram. The goal was to connect with as many people as possible without boundaries or limitations. Instagram was selected because it was the most popular social media and easy to access. Another goal of the Kogeomefi project was to encourage the public to stay productive among the limitations and use their spare time by making art. Finally, the method was expected to educate the public on choreography in a simple way.

\subsection{Innovation in the Virtual-based Dance Creation Method}

Driven by the hunger for creation and curiosity, an innovation emerged in the method of creating a dance piece virtually. Typically, in order to create a dance piece, there needs to be a direct interaction between the dancer and the choreographer. This study attempts a different method by using the internet and social media to accommodate the distance. A performance art cannot be separated from two main components, i.e. the performers (choreographers, dancers, the production team) and the audience. This also applies in the virtualbased piece, as the participation of dancers, choreographers, and music are central despite working in their respective space.

The project begins by Ferry posting invitations to produce a collaborative work on his personal account's Instagram story to the public of all levels, regardless of their artistic background. This is then followed by posting the process of the collaborative project. Those involved in the process are called the collaborators. The Kogeomefi method works as follows:

a) Collaborators send pictures of dance poses by posting the pictures on their respective account and tagging Ferry's Instagram account as the creator, as can be seen in Figure 3.

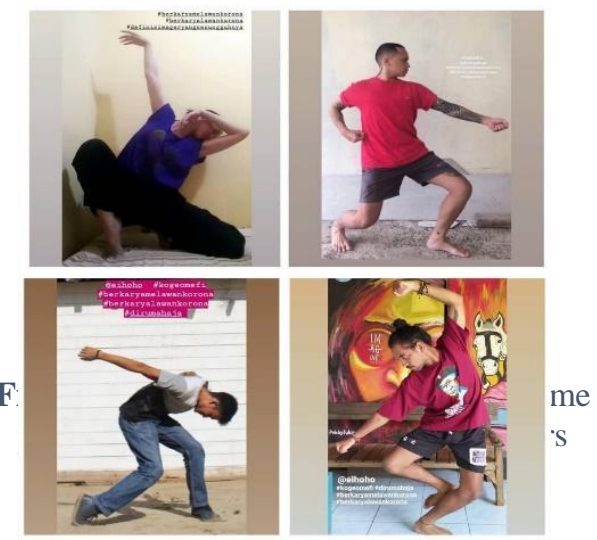


b) The dance poses are received and assembled into a complete dance piece by the dancer, as can be seen in Figure 4 below.

c) The collaborative piece is posted on the creator's Instagram account for the Instagram users as the audience to see.

According to Ferry, this method can be applied in the teaching learning process for students as it has the potential to improve their creativity and crating skills, with a more flexible and varied learning method which can be done anywhere and anytime [4]. On the other hand, the use of the social media Instagram becomes one of the points of attraction of this method as the application has an unlimited and extensive outreach. Moreover, Instagram is one of the social media platforms that are widely used by the millennials, and therefore may serve as an effective means to promote and introduce dance to the people of all generations.

\section{CONCLUSION}

Social media certainly have beneficial and harmful impacts in human lives and the users, especially if it is in the hands of irresponsible people. Today, social media is not merely a medium for communication, entertainment, and sharing information, but also for creation and innovation. One can even earn money and make a living through social media. The dance creation method through the social media Instagram is the result of innovation in the dance creation process which has a great potential in the development of dance studies, not only in terms of the creative process, but also in the scope of education, as the method has the potential to improve creativity, appreciation, and the creation skills among students.

\section{REFERENCES}

[1] Direktorat Jendral Informasi dan Komunikasi Publik. Memaksimalkan Penggunaan Media Sosial dalam Lembaga Pemerintah [Maximizing the Use of Social Media in Government Institutions]. Dirjen Informasi dan Komunikasi Publik Kemenkominfo, 2018.

[2] Hadi, Y.Sumandiyo. Koreografi Bentuk - Teknik - Isi [Choreography Form - Technique - Content]. Cipta Media, 2014.

[3] Koenjtaraningrat, Pengantar Ilmu Antropologi [Introduction to Anthropology]. Rineka Cipta, 2015.

[4] Nugroho, Ferry C. Ferry's Living Room, Final Exam Presentation. Youtube, 16 Apr. 2020, https://youtu.be/8K5YwRn_CnA
[5] Nur,aini, Indah L. Pembelajaran Matematika Geometri Secara Realistis Dengan GeoGebra [Learning Mathematical Geometry Realistically with GeoGebra]. Jurnal Teori dan Terapan Matematika, vol. 16, no. 2, 2017, pp. 1-6. DOI: 10.29313/jmtm.v16i2.3900

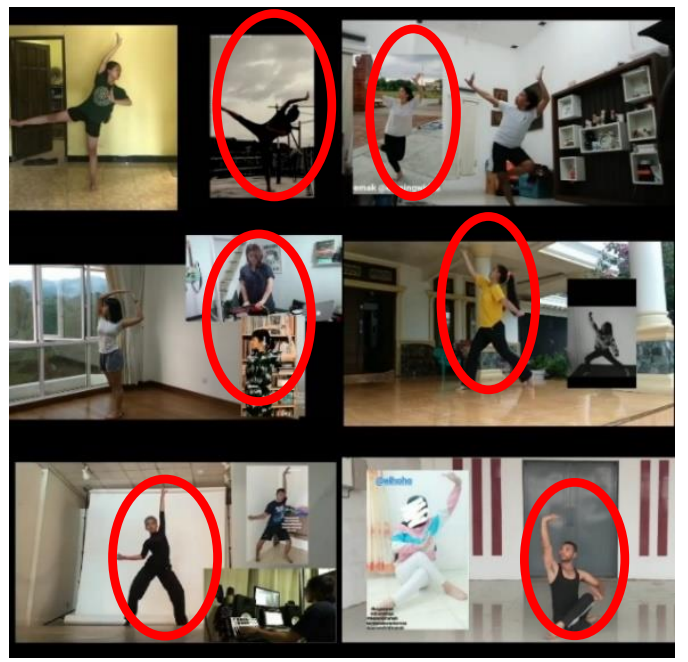

Figure SEQ Figure I* ARABIC 3. The original dance poses by the collaborators 